\title{
PEMBAHARUAN SISTEM PENDIDIKAN ISLAM DI PESANTREN
}

\author{
Husnul Amin \\ Sekolah Tinggi Ilmu Tarbiyah Raudhatul Ulum Sakatiga \\ Email:husnulamin2020@gmail.com
}

\begin{abstract}
Abstrak
Pesantren adalah lembaga yang bergerak di bidang pendidikan, maka tuntutan untuk memperbaharui system pendidikannya adalah keniscayaan agar menjadi sebuah institusi pendidikan modern yang siap berkompetisi dan bersaing dengan lembaga-lembaga pendidikan lainnya, Untuk itulah perlu satu sistem pendidikan yang komprehensif yang dapat difungsikan melalui transmisi baik dalam bentuk pendidikan formal maupun nonformal yang pada akhirnya dapat mengaktualisasikan hakikat hidup manusia karena manusia selalu terlibat dalam berbagai perubahan zaman. Oleh karena itu, dinamika pesantren masa depan tidak bisa dipisahkan dari proses globalisasi. Sebaliknya justru eksistensi pesantren masa depan sangat ditentukan oleh kemampuannya berintegrasi secara kultural dengan sistem internasional, yang ditandai dengan tata hubungan yang semakin rasional, dinamis, dan kompetitif.
\end{abstract}

Kata Kunci: Pembaharuan, Sistem Pendidikan Islam, Pesantren

\section{Pendahuluan}

Sistem pendidikan pesantren berangkat dari sumber ajaran Islam, namun terdapat perbedaan filosofis dalam memahami dan menerapkan ajaran-ajaran Islam pada bidang pendidikan sesuai dengan kondisi sosial budaya masyarakat yang melingkarinya. Perbedan-perbedaan itu pada dasarnya berpulang pada perbedaan pandangan hidup kyai yang mempimpin pesantren mengenai konsep, teologi, manusia, dan kehidupan, tugas dan tanggung jawab manusia terhadap kehidupan dan pendidikan. Dalam kenyataannya masing-masing pesantren mempunyai ciri khas sendiri-sendiri yang berbeda satu dari yang lain, sesuai dengan tekanan bidang studi yang ditekuni dan gaya kepemimpinan yang dibawakannya.

Sistem pendidikan pesantren didasari, digerakan dan diarahkan oleh nilai-nilai kehidupan yang bersumber dari ajaran dasar Islam. Ajaran dasar ini berkelindan dengan struktur kontekstual atau realitas sosial yang digumuli dalam hidup keseharian. Hasil perpaduan dari keduanya inilah yang membentuk pandangan hidup yang menetapkan tujuan pendidikan yang ingin dicapai serta pilihan cara yang akan ditempuh. Oleh karena itu, pandangan hidup seseorang selalu berubah dan berkembang sesuai dengan perubahan dan perkembangan realitas sosial yang dihadapi.

Dengan demikian, maka sistem pendidikan pesantren didasarkan atas dialog yang terus menerus antara kepercayaan terhadap ajaran dasar agama yang diyakini memiliki 


\section{Pembaharuan Sistem Pendidikan Islam di Pesantren Husnul Amin}

nilai kebenaran mutlak dan realitas sosial yang memiliki nilai kebenaran relatif. Nilai agama dengan kebenaran mutlak mempunyai supremasi atas nilai agama dengan kebenaran relatif, dan kebenaran nilai agama relatif ini tidak boleh bertentangan dengan nilai kebenaran mutlak. Dalam Islam, pemahaman terhadap ajaran dasar agama berpusat pada masalah tauhid atau ke-Esaan Tuhan (Mastuhu, 1994: 26).

Hakekat pendidikan pesantren terletak pada isi dan jiwanya. Isi pendidikan pondok pesantren terletak pada " pendidikan rohaniahnya ", yang pada masa lalu telah berhasil melahirkan kader-kader mubaliqh dan pemimpin-pemimpin umat dalam berbagai kehidupan (Zarkasy, 1973: 6). Pendidikan rohaniyah yang dimaksud adalah pembinaan iman dan amal seperti kebiasaan sholat berjamaah, etika dan sopan santun, ukhwah ( persaudaraan ), ta'awun (tolong menolong atau kooperatif ), ittihad ( persatuan ), thalabul ilmi ( menuntut ilmu ), ikhlas, jihad ( berjuang ), thaat ( patuh)

Dalam perkembangannya, banyak pondok pesantren yang mengembangkan isi pendidikannya dengan menambah berbagai komponen kurikuler ke dalam sistem pengajarannya, seperti kepramukaan, keterampilan, kesenian, kesehatan dan olahraga bela diri. Walaupun begitu, pendidikan rohaniah tetap menonjol, karena dijiwai oleh nilai-nilai keikhlasan, kesederhanaan, kemandirian, ukhuwah Islamiah, kebebasan yang terpimpin, kearifan, kebaktian ( ibadah ), keteladanan pemimpin dan sebagainya (Mastuhu, 1988: 281-282).

Pada mulanya pondok pesantren mempunyai pola pendidikan yang unik, yaitu hanya mengajarkan kitab-kitab turats, seperti; kitab Riyadhus Shalihin, Bulughul Maram, Tafsir Ayatul Ahkam dan lain-lain menurut taraf kemampuan santri, baik psikologis maupun kognitifnya. Metode pengajarannya menggunakan metode bandongan ${ }^{1}$ dan sorogan. ${ }^{2}$ Cara mengajar seperti ini masih berjalan, tapi pada dekade terakhir ini sudah banyak pesantren mengadopsi sistem madrasah dan sistem persekolahan dalam berbagai tingkatan di samping tetap menggunakan program pengajian kitab yang telah ada sebelumnya. Dengan menggunakan kurikulum madrasah dan sekolah pemerintah yang setingkat (Hasyim, 1988: 90), para lulusannya dikembangkan oleh pondok pesantren untuk dapat melanjutkan studinya ke sekolah dan madrasah pemerintah setingkat lebih tinggi, termasuk ke perguruan tinggi umum bagi lulusan madrasah Aliyah dan SMA-nya (Tebba, 1985: 273).

Dengan melihat terdapatnya kecenderungan perkembangan sistem pendidikan pondok pesantren, maka sebagian ahli pendidikan mengklasifikasikan sebagai berikut :

1. Pondok pesantren yang hanya terdiri dari masjid dan rumah kyai, yaitu para kyai menggunakan rumahnya sebagai tempat para santri belajar kitab dengan lebih banyak menggunakan metode hafalan dan metode tuntunan. Dahulu, pengajaran di pesantren dikenal dengan metode bandongan (seorang kyai membaca kitab, menerjemahkan dan menjelaskan maksud ibarat yang dibacanya dan santrinya menyimak bukunya sambil mencatat arti pada buku yang disimak tersebut ) dan

\footnotetext{
${ }^{1}$ Seorang kiai membaca kitab, menerjemakan dan menjelaskan maksud ibarat yang dibacanya dan santrinya menyimak bukunya sambil mencatat arti pada buku yang disimak tersebut.

${ }^{2}$ Kyai membaca suatu kitab dan santri menyimak dan menirukannya atau santri membaca kitabnya di depan kyai, kemudian kyai menyimak dan mengoreksi bacaannya kemudian menambah pelajaran untuk santri tersebut. 
P-ISSN : 2541-3686

sorogan (kyai membacakan suatu kitab dan santri menyimak dan menirukannya atau santri membaca kitabnya di depan kyai, kemudian kyai menyimak dan mengoreksi bacaannya kemudian menambah pelajaran untuk santri tersebut).

2. Pondok pesantren yang memiliki masjid, rumah kyai, asrama tempat tinggal santri serta menyelenggarakan pengajian kitab klasik dengan metode hafalan, tuntunan dan resitasi.

3. Pondok pesantren yang selain memiliki komponen pondok pesantren tradisional tersebut di atas, juga menyelenggarakan pendidikan formal seperti madrasah dalam berbagai tingkat. Dengan demikian, sistem pondok dan sistem persekolahan berjalan saling melengkapi antara keduanya.

4. Pondok pesantren yang telah memiliki komponen-komponen pondok pesantren pola ketiga, juga mengembangkan pendidikan keterampilan seperti, peternakan, kerajinan rakyat, koperasi, sawah dan ladang.

5. Pondok pesantren yang telah berkembang dan maju disebut pondok pesantren modern. Pondok pesantren ini di samping telah memiliki komponen fisik seperti pondok pesantren pola keempat tersebut, juga memiliki perpustakaan, dapur umum, ruang tamu, ruang makan, kantor administrasi, toko dan koperasi, gedung pertemuan, kamar mandi, WC, dan labolatorium yang memadai. Aktivitas pendidikannya adalah pengajian kitab, menyelenggarakan madrasah dan sekolah umum dari tingkat dasar hingga pendidikan tinggi serta pendidikan keterampilan dan juga program pengembangan lingkungan (Saridjo, 1979: 9-10).

Dari uraian di atas dapat dipahami bahwa dari segi aktivitas pendidikan yang dikembangkan, maka pondok pesantren dapat diklasifikasikan dalam beberapa tipe, yaitu:

a. Pondok pesantren yang hanya menyelenggarakan pengajian kitab dengan sistem sorogan, bandongan dan wetonan.

b. Pondok pesantren yang menyelenggarakan pendidikan campuran antara sistem pengajian kitab tradisional dengan madrasah formal dan mengadopsi kurikulum pemerintah.

c. Pondok pesantren yang menyelenggarakan pola campuran antara sistem pengajian kitab tradisional, sistem madrasah dan sistem sekolah umum dengan mengadopsi kurikulum pemerintah (kementerian agama dan kementerian pendidikan nasional) serta ditambah dengan kurikulum muatan lokal (pesantren modern).

\section{Pembaharuan Sistem Pendidikan di Pesantren}

Dengan mengacu kepada kecenderungan perkembangan pesantren di atas, maka dalam upaya pembaharuan sistem pendidikan dapat menyertakan satu atau bahkan beberapa aspek yang akan diperbaharui. Hal itu pada umumnya tergantung dari latar belakang dan tujuan yang dilakukannya pembaharuan tersebut oleh lembaga penyelenggara pendidikan. Maka dalam proses pendidikan terjadi pembaharuan pendidikan dalam berbagai aspek. Misalnya, pembaharuan dalam aspek tujuan 


\section{Pembaharuan Sistem Pendidikan Islam di Pesantren Husnul Amin}

pendidikan, aspek pendidik, aspek peserta didik, aspek materi/kurikulum, dan aspek metode pendidikan

\section{a. Aspek Tujuan Pendidikan Pesantren}

Tujuan pendidikan pesantren adalah untuk mewujudkan dan mengembangkan kepribadian muslim, yaitu kepribadian yang beriman dan bertaqwa kepada Tuhan Yang Maha Esa, berakhlak mulia, bermanfaat bagi masyarakat, berkhidmat kepada masyarakat dan kyai dengan jalan menjadi kawula ( mengikuti sunah Nabi ), mampu berdiri sendiri, bebas dan teguh dalam kejayaan Islam ditengah masyarakat, mencintai ilmu dan mengembangkan kepribadian Indonesia (Mastuhu, 1994: 55).

Tujuan merupakan aspek yang sangat penting dalam proses pendidikan dan pengajaran, karena mengarahkan proses untuk tercapainya tujuan yang telah ditetapkan, meliputi tujuan pendidikan nasional, tujuan institusional, tujuan kurikuler, tujuan intruksional umum, tujuan instruksional khusus, Seperangkat tujuan tersebut merupakan rangkaian yang saling terkait hingga terukur yaitu tujuan institusional khusus (Wijaya, dkk., t.th: 34).

Tujuan harus ada sebelum melangkah untuk mengerjakan sesuatu. Bila pendidikan dipandang sebagai suatu proses, maka proses tersebut akan berakhir pada tercapainya tujuan akhir pendidikan (Arifin, 1987), hlm.119. Oleh karena itu, usaha yang tidak mempunyai tujuan tidaklah mempunyai arti apa-apa. Tujuan pendidikan suatu masyarakata selalu dibangun di atas falsafah masyarakat yang bersangkutan dan merupakan refleksi dari nilai-nilai ideal yang diasumsikan dapat melahirkan nilai etis dan pragmatis yang bermanfaat bagi anggota masyarakat tersebut secara keseluruhan. Sebagaimana diketahui bahwa suatu masyarakat selalu bersifat dinamis, dan mengalami perkembangan dan perubahan dari zaman ke zaman sehingga pembaharuan tujuan pendidikan merupakan hal yang tak terelakkan (Nuraeni, 2004: 41).

Berbicara tentang tujuan pendidikan maka erat kaitannya dengan tujuan hidup manusia, karena pendidikan hanyalah sebagai alat yang digunakan manusia untuk memelihara kelanjutan hidupnya, baik sebagai individu maupun sebagai masyarakat. Oleh karena itu, tujuan pendidikan harus diarahkan sesuai dengan kebutuhan dan tuntutan yang sedang dihadapi (Langgulung, 1995: 147). Dengan istilah lain, pembaharuan tujuan pendidikan selalu dimaksudkan untuk mereformasi berbagai rencana dan kegiatan sehingga proses pendidikan tidak kehilangan relevansi dengan tuntutan kebutuhan masyarakan baik yang bersifa lokal, nasional, regional maupun internasional atau global. Disini nampak bahwa tujuan pendidikan di zaman Reformasi (era global) setidaknya mencoba mengarahkan atau menunjukan sesuatu yang hendak dituju dalam proses pendidikan.

Dalam konteks ini, aliran pendidikan Progressivisme mempunyai andil yang kuat dalam dinamika masyarakat yang selalu berubah. Aliran yang lahir sebagai pembaharuan dalam dunia pendidikan terutama sebagai lawan terhadap kebijakankebikajan konvesional yang diwarisi dari abad ke-9 ini boleh dikatakan banyak berbuat dan melakukan inisiatif buat mengadakan rekonstruksi di dalam pendidikan modern. 
Volume 1 Nomor 1 Edisi Juni 2016

P-ISSN : 2541-3686

Aliran ini anti terhadap kemutlakan, menolak absolutisme, dan ototiterisme, serta bersifat dinamis, dan selalu mengalami perubahan (Jalaluddin dan Idi, 1997: 73).

Progress atau kemajuan itu menimbulkan perubahan, dan perubahan menimbulkan pembaharuan. Suatu pembaharuan menghendaki keaslian dan kewajaran, dan bukanlah semata-mata penjelmaan dari suatu realitas yang sudah ada dengan lengkap sempurna lebih dulu. Pendidikan progresif tidaklah dikatakan progresif oleh karena dia segera mantap membuat kemajuan untuk menuju kepada tujuan yang telah ditetapkan, akan tetapi karena dia tumbuh dan berkembang kearah manapun juga, menuju suatu masa depan baru yang memberikan kemungkinan terbanyak buat mencapai perkembangan dan kemajuan. ${ }^{3}$

Menurut Brubacer, progresif adalah sifat alamiah, kodrati, dan itu adalah perubahan, dan perubahan berarti suatu yang baru, suatu yang baru sunguh-sungguh merupakan keadaan yang nyata dan bukan sekedar pengertian atas realita yang sebelumnya memang sudah demikian (Syam, 1986: 226). Dalam banyak hal Progressivisme itu identik dengan Pragmatisme. Apabila orang menyebut Pragmatisme maka berarti Progressivisme, begitu sebaiknya. ${ }^{4}$ Menurut falsafah Pragmatisme bahwa keadaan selalu berubah dalam frekuensi yang berbeda-beda, mementingkan eksperimen (percobaan), perubahan dalam daya cipta, menghormati kebebasan, bakat-bakat, kebolehan-kebolehan, kebutuhan-kebutuhan, minat, keinginan-keinginan dan perbedaan perseorangan di antara individu-individu, manusia punya sifat dinamis dan kreatif. Tujuan pendidikan adalah melatih agar anak kelak dapat bekerja secara sistematis, mencintai kerja dan bekerja dengan otak dan hati. Pelaksanaan pendidikan diarahkan pada pengembangan minat dan bakat setiap peserta didik. ${ }^{5}$ Model kurikulum berupa kurikulum yang mendorong munculnya pengalaman-pengalaman peserta didik dan kegiatan-kegiatan pembelajaran yang diminati oleh semua (Zurinal dan Sayuti, 2006: 24).

Pragmatisme sebagai aliran filsafat (Pragmatisme) sebagai filsafat pendidikan merupakan aliran fikir yang telah dituliskan oleh John Dewey. Sumbangan John Dewey

\footnotetext{
${ }^{3}$ H.B. Hamdani Ali, Filsafat Pendidikan ,Yogyakarta: Kota Kembang,1986, h. 147; Progresif memandang sesuatu harus pragmatis dalam kemanfaatan. Nilai-nilai yang dianut bersifat dinamis dan berubah. Pendidikan sebagai alat untuk memproses dan merekontrusi kebudayaan baru haruslah dapat menciptakan situasi yang edukatif yang pada akhirnya akan dapat memberikan corak dari out-put yang dihasilkan sehingga keluaran yang dihasilkan adalah manusia-manusia yang berkualitas, unggul, kompetitif, inisiatif, adaftif, dan kreatif serta sanggup menjawab tantangan zamannya. Djunaidatul Munawwaroh dan Tanenji, Filsafat pendidikan;Perpektif Islam dan Umum (Jakarta:UIN Jakarta Press,2003), h.75.

${ }^{4}$ Aliran ini disebut juga instrumental, eksperimental dan environmental (intelegensi,praktek dan lingkungan). Lihat: John S. Brubacher, Modern Philosophies of Education (New York: Mc.Graw-Hill Book Company, 1950), h. 297; Jalaluddin dan Abdullah Idi, Filsafat Pendidikan, h. 72; Djunaidatul Munawwaroh dan Tananji, filsafat Pendidikan, h. 70 dan 74.

${ }^{5}$ Pragmatisme, memahami anak didik dapat menghayati belajar yang edukatif. Maksudnya, belajar untuk mencapai hasil-hasil yang secara konstruktif, yang nilainya dan syarat-syaratnya ditentukan berdasarkan konsepsi tentang hidup yang baik dan kebudayaan sebagaimana yang dikehendaki oleh suatu Negara atau bangsa. Dan pendidikan atau pengajaran tersebut besesuaian dengan tujuan. Lihat: Imam Bernadib, filasafat Pendidikan: Sistem \& metode (Yogyakarta: ANDI, 1994) h.35
} 


\section{Pembaharuan Sistem Pendidikan Islam di Pesantren Husnul Amin}

ini dipandang sebagai kekuatan intelektual yang dapat menggerakan perkembangan Progressivisme. $^{6}$

Dalam merumuskan tujuan pendidikan pesantren, agaknya tidak banyak kyai pesantren yang mampu secara sadar merumuskan tujuan pendidikannya dan menuangkan dalam rencana kerja atau program. Tidak adanya rumusan tujuan itu disebabkan adanya kecenderungan visi dan tujuan pesantren sepenuhnya berada di tangan kyai yang bersangkutan atau bersama-sama dengan para pembantunya (badal) secara intuitif dan diseesuaikan dengan suasana pesantrennya (Madjid, 1997: 6). Maka tidak heran kalau timbul anggapan bahwa hampir semua pesantren itu merupakan hasil usaha pribadi atau individual (individual enterprise)

Seiring dengan perkembangan dan tuntutan zaman, pesantren dituntut memiliki arah dan tujuan yang jelas untuk dijadikan acuan dan target yang akan dicapai. Sehingga tujuan pendidikan pesantren dapat membentuk manusia yang memiliki kesadaran tinggi bahwa ajaran Islam merupakan nilai-nilai yang bersifat menyeluruh. Selain itu produk pesantren ini diharapkan memiliki kemampuan tinggi untuk mengadakan respon terhadap tantangan-tantangan dan tuntutan-tuntutan hidup dalam konteks ruang dan waktu yang ada. Dengan demikian, para pengelola pesantren yaitu kyai dituntut kerja keras dan berupaya mewujudkan tujuan tersebut.

\section{b. Aspek Kurikulum Pesantren}

Istilah kurikulum berasal bahasa Latin, yaitu currere yang berarti lari, lapangan pertandingan, dan tempat perlombaan atau jarak yang harus ditempuh, yang pada masa lalu digunakan oleh pemain olahraga (Ishak, 1998: 4, Soedarminto dkk., 1999: 3). Jadi secara harfiah kurikulum mengandung arti perlombaan, pacuan, dan pertandingan. Sedangkan kurikulum dalam pendidikan Islam dikenal dengan kata manhaj yang berarti jalan terang yang dilalui manusia pada berbagai bidang kehidupan (Ramayulis,. 2010: 61). Para ahli pendidikan banyak memberikan batasan arti kurikulum, baik dalam pengertian sempit maupun dalam pengertian luas. Dalam pengertian sempit kurikulum diartikan sebagai sejumlah mata pelajaran atau sejumlah pengetahuan yang harus dikuasai untuk mencapai suatu ijazah. Kurikulum dapat juga berarti keseluruhan pelajaran yang diberikan oleh suatu lembaga pendidikan. ${ }^{7}$ Sementara kurikulum dalam pengertian luas, yaitu kurikulum yang menyangkut semua kegiatan yang dilakukan dan dialami peserta didik dalam perkembangan baik formal maupun informal guna mencapai tujuan pendidikan (Suryanto dan Hisyam, 2000: 59).

Kurikulum menurut William B. Ragan yang dikutip oleh S. Nasution adalah seluruh program dan kehidupan dalam sekolah, yaitu segala pengalaman peserta didik

\footnotetext{
${ }^{6}$ Selain John Dewey, tokoh Progressivisme yang lain adalah William james. Lihat: Imam Bernadib, Filsafat Pendidikan, h. 34 Jalaluddin dan Abdullah Idi, Filsafat Pendidikan, h. 72; H.B. Hamdani Ali, Filsafat Pendidikan, h. 143 dan 148.

${ }^{7}$ Pengertian ini nampaknya mengacu pada sejumlah mata pelajaran yang diberikan di dalam kelas. Dengan demikian, kurikulum dalam pengertian ini hanya terbatas kepada apa yang diberikan oleh pendidik di dalam kelas. Jika kurikulum hanya dipahami secara sempit, maka dinamika proses belajar mengajar serta kreativitas pendidik dan peserta didik terhenti atau mandeg. Lihat:Omar Muhammad al-Toumy al-Syaibani, Filsafat Pendidikan Islam. Penerjemah hasan Langgulung, Jakarta: Bulan Bintang, 1979, h. 478.
} 
Volume 1 Nomor 1 Edisi Juni 2016

P-ISSN : 2541-3686

di bawah tanggung jawab sekolah. Kurikulum tidak hanya meliputi bahan pelajaran tetapi juga meliputi seluruh kehidupan dalam kelas (Nasution, 2003: 3; Sukmadinata, 1999: 103). Menurut Undang-undang Sistem Pendidikan Nasional Nomor 20 Tahun 2003, kurikulum adalah seperangkat rencana dan pengaturan mengenai tujuan, isi dan bahan pelajaran serta cara yang digunakan sebagai pedoman penyelenggaraan kegiatan pembelajaran untuk mencapai tujuan pendidikan tertentu (Undang-undang RI Nomor 20 Tahun 2003 tentang Sistem Pendidikan Nasional).

Dari berbagai defenisi kurikulum di atas dapat dipahami bahwa kurikulum secara signifikan berperan sebagai pedoman dan landasan operasional bagi implementasi proses belajar mengajar di sekolah, lembaga pendidikan dan pelatihan. Hal tersebut diharapkan dapat menimbulkan perubahan tingkah laku, sekaligus alat dan sarana untuk mencapai tujuan pendidikan. Bila ditinjau dari segi organisasinya, ${ }^{8}$ kurikulum terbagi dalam tiga tipe atau bentuk, yaitu :Separated Subject Curriculum, Correlative Curriculum, dan Integrated Curriculum. ${ }^{9}$

Adapun Separated Subject Curriculum yaitu kurikulum yang berisis sejumlah mata pelajaran yang terpisah-pisah. ${ }^{10}$ Kurikulum ini mudah disusun, direorganisasi, diubah, ditambah dan dikurangi. Perbaikan dan perubahan kurikulum dilakukan dan dicapai dengan menambah atau mengurangi jumlah, isi atau jenis mata pelajaran sesuai dengan permintaan zaman. Sehingga, mata pelajaran yang dirasa tidak sesuai lagi, dapat ditiadakan (Nasution, 2003: 180-184).

Sedangkan Correlative Curriculum yaitu kurikulum yang berisi sejumlah mata pelajaran yang sejenis dihubung - hubungkan. ${ }^{11}$ Menghubungkan mata pelajaran yang satu dengan yang lain dengan memelihara identitas mata pelajaran, atau menyatupadukan mata pelajaran dengan menghilangkan identitas mata pelajaran dalam bidang studi tertentu. Paduan atau fusi antara beberapa mata pelajaran itu disebut Broad Field (Nasution, 2004: 192). Sementara Integrated Curriculum yaitu kurikulum yang terdiri

\footnotetext{
${ }^{8}$ Menurut S. Nasution, yang dimaksud dengan organisasi kurikulum adalah pola atau bentuk susunan bahan pelajaran yang disampaikan kepada peserta didik, dan merupakan suatu dasar yang sangat penting dalam pembinaan kurikulum dan bertalian erat dengan tujuan program pendidikan yang hendak dicapai. Lihat: S. Nasution, Asas-asas Kurikulum, hlm. 176.

${ }^{9}$ S. Nasution, Asas-asas Kurikulum, cet. III, h. 176-227; R. Ibrahim dan Benny Karyadi, Materi Pokok Pengembangan Inovasi dan Kurikulum, cet. II ,jakarta: Penerbit Universitas Terbuka, 1994. hlm. 17; Syafruddin Nurdin, guru profsional \& Impementasi Kurikulum (Jakarta: Ciputat Press, 2002), hlm.44; Sementara itu menurut Subandijah, ada beberapa istilah yang dikenal dalam organisasi kurikulum yaitu; correlated curriculum, integrated curriculum, fuse curriculum dan core curriculum. Subandijah, Pengembangan dan Inovasi Kurikulum (Jakarta: PT. Rajagrafindo Persada, 1993), hlm. 13; sedangkan menurut iskandar Wiryokusumo dan Usman Mulyadi, unit-unit kurikulum tersebut meliputi; separated subject curriculum, correlated curriculum, integrated curriculum dan development curriculum. Lihat Iskandar wiryokusumo dan Usman Mulyadi, dasar-dasar Pengembangan Kurikulum (Jakarta: Bina Aksara, 1988), hlm. 18.

${ }^{10}$ R. Ibrahim dan Benny Karyadi, Materi Pokok Pengembangan Inovasi dan Kurikulum, hlm. 17; S. Nasution, Asas-asas Kurikulum, hlm. 178; Iskandar Wiryokusumo dan Usman Mulyadi, dasar-dasar Pengembangan, h. 18; Syafruddin Nurdin, Guru Profesional \& Implementasi Kurikulum, hlm.44.

${ }^{11}$.R. Ibrahim dan Benny Karyadi, Materi Pokok Pengembangan Inovasi dan Kurikulum, hlm. 17; S. Nasution, Asas-asas Kurikulum, hlm. 191-192; Iskandar Wiryokusumo dan Usman Mulyadi, dasar-dasar Pengembangan, hlm. 19; Syafruddin Nurdin, Guru Profesional \& Implementasi Kurikulum, h.46.
} 


\section{Pembaharuan Sistem Pendidikan Islam di Pesantren Husnul Amin}

dari peleburan semua/hampir semua mata pelajaran. ${ }^{12}$ Kurikulum ini meniadakan batasbatas antara berbagai mata pelajaran dan menyajikan bahan pelajaran dalam bentuk unit atau keseluruhan.

Jika hal tersebut dikaitkan dengan dunia pesantren, maka ditemukan salah satu keunikan pesantren salafiyah adalah adanya independensi dan tidak mau terikat dengan pemerintah atau pihak manapun termasuk dalam menentukan dan melaksanakan kurikulum pembelajarannya baik written maupun hidden kurikulumnya. Kyai bebas menentukan kurikulum pendidikannya sesuai dengan keahlian yang ada pada dirinya dan kebutuhan para santrinya. Oleh karena itu biasanya antara satu pesantren dengan yang lain berbeda - beda dan menjadi ciri khas pesantren tersebut. Ada pesantren yang secara khusus mengkaji ilmu fiqih sehingga terkenal menjadi pesantren fiqih, ada juga pesantren hadist, pesantren ilmu alat-alat (nahwu dan saraf) dan sebagainya. Ada juga pesantren yang terkenal dengan agri bisnisnya karena secara khusus para santrinya belajar pertanian dan peternakan sebagaimana pesantren Al Ittifaq di Ciwiday Bandung Jawa Barat ${ }^{13}$.

Karena tidak adanya tingkatan maupun penjenjangan, pesantren salafiyah tidak mengenal batasan waktu belajar bagi para santri. Mereka bebas memilih mau berapa di pesantren sesuai keinginan dan hasil yang diperoleh serta restu kyai. Oleh karena itu santri yang memasang target berapa tahun untuk belajar di sebuah pesantren salafiyah. Walapun ada perjenjangan hanya untuk mempermudah pengelompokan santri. Tingkatan biasanya didasarkan pada nama- nama kitab yang dipelajarinya seperti tingkat Jumuriyah, tingkat'Imriti, tingkat Alfiyah dan seterusnya. Ada juga yang menggunakan tingkat ula, wushtho, dan 'ulya dimana para santri dikelompokan sesuai keahliannya dan berapa banyak kitab yang dipelajari.

Adapun kurikulum yang dipergunakan pesantren salafiyah yang bersumber pada kitab-kitab muqaddimah ( kitab kuning / al kutub al shafra )14. Kitab-kitab yang dipakai pesantren kebanyakan kitab-kitab bermadzhab Syafi'i. Kitab-kitab yang digunakan terdiri dari beberapa disiplin ilmu meliputi bidang aqidah/ tauhid, tajwid, (al-Qur'an), akhlak/tasawuf, Bahasa Arab, ( nahwu, sharaf, balaghoh ), fiqih, ushul fiqih, tafsir, 'ulum al-Qur'an, hadist, 'ulum al hadist dan tarikh/ sejarah Islam.

\footnotetext{
${ }^{12}$ R. Ibrahim dan Benny Karyadi, Materi Pokok Pengembangan Inovasi dan Kurikulum, hlm. 17; S. Nasution, Asas-asas Kurikulum, hlm. 196; Iskandar Wiryokusumo dan Usman Mulyadi, dasar-dasar Pengembangan, hlm. 20; Syafruddin Nurdin, Guru Profesional \& Implementasi Kurikulum, hlm.48.

${ }^{13}$ Observasi penulis pada Studi Banding pesantren pada tanggal 9 Juli 2010. Di pesantren Al Ittifaq Ciwiday disamping mengaji kitab - kitab kuning (fiqih, hadist, tafsir, nahwu, sharaf, dan lainnya) para santri wajib belajar pertanian, peternakan dan perikanan sesuai dengan pilihannya. Ada juga yang memilih perbengkelan, elektronik dan konveksi walaupun tidak banyak peminatnya. Dalam bidang pertanian para santri belajar dan mempraktekkan cara bertanam strawberry dan sayur-sayuran. Santri yang memilih bidang peternakan mereka belajar dan mempraktekkan peternakan sapi, kambing dan ayam. Sedangkan perikanan mereka belajar dan peraktek memelihara ikan mujair, guramih dan lele dumbo. Meski demikian kebanyakan para santri memilih pertanian dan peternakan dengan hasil yang bagus dan terkenal berkuaitas tinggi sehingga pemasarannya mampu menembus mini-mini market terkenal di Bandung, Jakarta dan sekitarnya.

${ }^{14}$ Disebut al-kutub, al-qodimah karena kitab - kitab tersebut dikarang ratusan tahun yang lalu. Sedangkan disebut al-kutub al shafra ( kitab kuning ) karena kebanyakan kitab - kitab tersebut dicetak dengan ker tas berwarna kuning. Dalam penyajian materi kitab kuning ada yang berbentuk kitab - kitab natsar (esai ), nazham ( syair ), matn ( isi ), Syarh/Hasysyah ( uraian ) dan muktashar (ringkasan). Lebih rinci lihat M. Syamsul Hadi dkk, Pengembangan Metodologi Pembelajaran Pesantren Salafiyah,( Jakarta, Diva Pustaka, 2002), hlm. 13-19.
} 
Di samping belajar kitab- kitab kuning para santri juga mendapatkan pelajaran tambahan berupa belajar berpidato (muhadlarah), tahlilan, seni baca Al-Qur'an (naghom), berzanji dan lain-lain dilaksanakan pada waktu-waktu kosong di luar jadwal pengajian di bawah koordinasi santri-santri senior. Para santri juga belajar keterampilan hidup ( life skill ) seperti pertanian, peternakan dan perbengkelan.

Adapun pesantren khalafiyah karena sudah mengadopsi sistem pendidikan formal baik madrasah maupun sekolah, maka kurikulum yang digunakan adalah kurikulum perpaduan antara kurikulum pesantren dengan kurikulum Departemen Agama bagi madrasah dan kurikulum Departemen Pendidikan Nasional bagi sekolah. Karena di samping para santri belajar kitab kuning, mereka juga belajar secara klasikal di kelas. Cara memadukan kedua kurikulum bervariasi ada yang terpisah dengan menerapkan $100 \%$ kurikulum umum dan $100 \%$ kurikulum pesantren dengan pembagian pagi hari santri belajar di madrasah/sekolah sedangkan sore dan malam harinya pengajian atau Madrasah Diniyah yang secara khusus belajar kitab-kitab kuning. Ada juga pesantren yang menggabungkan kurikulum lokal 70\% dan kurikulum nasional $30 \%$. Di samping itu ada juga pesantren modern yang mempunyai kurikulum sendiri dengan tidak sama sekali mengadopsi kurikulum nasional tetapi lulusannya diakui pemerintah seperti Pesantren Modern Darussalam Gontor. ${ }^{15}$

Para santri di pesantren khalafiyah bukan saja belajar sesuai kurikulum yang ditentukan baik lokal maupun kurikulum nasional, mereka juga belajar berbagai ilmu lain sebagai kegiatan ekstrakurikuler seperti penguasaan bahasa Arab dan Inggris, keterampilan, olahraga dan kesenian, berpidato dan kegiatan - kegiatan lain yang dikoordinir oleh Bagian Pendidikan dan Pengajaran serta pengurus organisasi santri. Sistem Pendidikan Pesantren menggunakan pendekatan holistik, dimana kegiatan belajar mengajar merupakan kesatupaduan dan lebur dalam totalitas kehidupan sehari-hari. Karena tinggal di kompleks pesantren selama 24 jam adalah nuansa kependidikan (full day scholl).

Bicara masalah pembaharuan kurikulum, maka erat kaitannya dengan kebutuhan manusia. Di mana kebutuhan manusia terus berubah, bertambah, dan dinamis sesuai dengan tuntutan masa. Kalau ingin kurikulum sesuai dengan kebutuhan dan tuntutan masa, maka seyogyanya diadakan pembaharuan terus-menerus (Tarigan, 1993: 135).

Pembaharuan kurikulum dilakukan karena kurikulum adalah suatu yang bersifat dinamis dan mengikuti perubahan nilai-nilai budaya masyarakat sesuai arus perkembangan IPTEK. Artinya, kurikulum sebagai alat untuk mencapai tujuan pendidikan selalu menyesuaikan dengan perkembangan masyarakat yang selalu berubah. Kurikulum dibuat mesti bermanfaat bagi siswa dan membantu menyelesaikan masalah mereka dan masalah masyarakat. ${ }^{16}$

\footnotetext{
${ }^{15}$ Abdullah Syukri Zarkasyi, Manajemen Pesantren Pondok Pesantren Modern Gontor, Ponorogo, Trimurti Press, 2005 ), cet. Ke-2,hlm. 17 Kurikulum Gontor terdiri dari $100 \%$ ilmu agama dan 100\% umum, dengan subjek umum terdiri dari Bahasa Arab, Dirasah Islamiyah, Ilmu Keguruan, Bahasa Inggris, Ilmu Pasti, Ilmu Pengetahuan Alam, Ilmu Pengetahuan Sosial, Kewarganegaraan.

${ }^{16}$ Kurikulum harus terbuka, kemungkinan akan adanya peninjauan, fleksibel, dapat direvisi dan dievaluasi setiap saat sesuai dengan kebutuhan setempat. Sehingga, penerapan kurikulum tersebut dapat mengembangakan
} 


\section{Pembaharuan Sistem Pendidikan Islam di Pesantren Husnul Amin}

Subandijah membedakan istilah pembaharuan kurikulum dengan perubahan kurikulum. Kalau pembaharuan kurikulum, menurutnya adalah perubahan atau inovasi kurikulum dalam mata pelajaran atau bidang studi. Atau disebut juga dengan perubahan kurikulum dalam skala terbatas (mikro/khusus). Sedangkan perubahan kurikulum adalah perubahan kurikulum di segala aspek dalam komponen kurikulum. Atau disebut juga dengan perubahan kurikulum secara (makro/umum). ${ }^{17}$

Sejalan dengan alur ini, maka pembaharuan kurikulum dapat ditandai dengan adanya mata pelajaran baru yang diperkenalkan. Atau dapat pula berupa perubahan jam dan mata pelajaran, baik dalam bentuk penambahan maupun pengurangan sesuai dengan kebutuhan zaman.

\section{c. Aspek Metodologi Pembelajaran di Pesantren}

Metodologi pembelajaran yang berlaku pada saat ini tampak masih "klasik", dalam arti mewariskan sejumlah materi ajaran agama yang diyakini benar untuk disampaikan kepada anak didik tanpa memberikan kesempatan padanya agar disikapi secara kritis. Sesuai dengan itu, metodologi mengajar dan belajar sistem pendidikan Islam Indonesia sampai kini masih bercorak menghafal, dan mekanisme lebih mengutamakan penghayatan materi, tentu saja metodologi semacam ini cenderung memandang ilmu dari segi akhirnya semata, bukan dari segi prosesnya.

Pada pesantren salafiyah metode pembelajaran yang digunakan terdiri dari metode sorogan, wetonan/bandongan, halaqah, hafalan/ tahfizh, bahtsul masail, hiwar, fathul kutub dan muqaranah. Sorogan (Jawa) yang berarti menyodorkan adalah metode yang mengutamakan pada kemampuan individu santri di mana setiap santri menghadap kyai satu persatu untuk membaca dan member makna kitab sementara kyai membimbing santri. ${ }^{18}$ Wetonan dan Bandongan, adalah metode kuliah di mana kyai mengumpulkan santri -santrinya dalam satu tempat untuk mendengarkan penjelasan kyai sambil memberi makna pada kitab masing-masing. Dalam metode ini juga santri cukup pasif karena tidak terjadi dialog. Halaqoh, adalah metode belajar berkelompok untuk membahas/mendiskusikan satu topik yang merupakan isi dalam salah satu kitab. Metode ini bertujuan untuk mengembangkan intelektual santri dalam memahami isi kitab sehingga cukup efektif karena santri cukup dinamis karena terjadi dialog antar mereka bahkan biasanya santri senior yang memimpin pembelajaran sedangkan kyai

minat, kreativitas, produktivitas, dan merangsang perubahan psikologis peserta didik. Disamping itu, dapat pula mengembangkan aspek kognitif dan psikomotor peserta didik dalam rangka pengembangan dan pembentukan kepribadiannya. Lihat: Omar mohammad Al-Toumy, falsafah Pendidikan Islam, H. 528-529; Jalaluddin dan Abdullah Idi, Filsafat Pendidikan, hlm. 78.

${ }^{17}$ Subandijah, Pengembangan dan Inovasi Kurikulum, h. 84; Senada dengan itu, Hendyat Soetopo dan Wasty Soemanto juga berpendapat, kalau perubahan yang terjadi hanya pada komponen (unsure) tertentu saha dari kurkulum, maka hal itu disebut dengan pembaharuan (inovasi/perubahan sebagian-sebagaian). Hendyat Soetopo dan wasty Soemanto, Pembinaan dan Pengembangan Kurikulum Sebagai Substansi Problem Administrasi Pendidikan, cet. IV , (Jakarta: Bumi Aksara, 1993), hlm. 38-39.

${ }^{18}$ M. Habib Hirzin, Ilmu dan Agama dalam Pesantren, (Jakarta, LP3ES, 1995), hlm. 88. Metode sorogan disamping memiliki kelebihan dapat mengetahui kemampuan masing - masing santri, tetapi juga memiliki kelemahan yaitu murid fasif karena tidak terjadi dialog antara murid dan guru karena lebih terpusat kepada guru. 
Volume 1 Nomor 1 Edisi Juni 2016

P-ISSN : 2541-3686

atau ustadz hanya memantau jalannya diskusi ${ }^{19}$. Metode halaqoh hampir sama dengan metode hiwar dan baths al masail. Bedanya metode hiwar untuk pengayaan atau memperdalam materi yang sudah dikaji sedangkan metode baths al masail topik yang didiskusikan lebih luas tidak terbatas pada satu kitab. Selanjutnya metode bahtsul masail dibantu dengan metode fathul kutub, di mana para santri diberi tugas untuk mencari rujukan dalam beberapa kitab terhadap suatu masalah yang kemudian dilengkapi dengan metode muqaranah dan para santri diberi tugas untuk membandingkan pendapat beberapa madzhab yang terdapat dalam berbagai kitab(Fatah, dkk. 2005: 67-72).

Pada pesantren khalafiyah para santri belajar paket-paket kurikulum yang telah ditentukan secara klasikal pada tingkatan dan jenjang yang sesuai dengan ijazah yang dimiliki sebelum masuk ke pesantren. Kurikulum yang mereka pelajari adalah kurikulum perpaduan kurikulum lokal dan kurikulum nasional atau kurikulum yang disusun secara khusus oleh pesantren.

Pesantren khalafiyah yang memiliki madrasah atau sekolah para santrinya ditutunt untuk mempelajari dua program yaitu program pondok dan program madrasah atau sekolah. Pada tahap evaluasi mereka juga mengikuti ujian madrasah /sekolah yang diselenggarakan pemerintah termasuk Ujian Nasional ( UN ) dan ujian pondok, mereka menerima dua buah rapot dan ketika selesai mendapatkan dua ijazah yaitu ijazah pondok dan ijazah negeri.

Metode yang dipakai para ustadz dalam proses pembelajaran adalah metode modern yaitu di samping metode ceramah para ustadz juga menggunakan metode Tanya jawab, diskusi, drill, problem solving, dan metode active learning lainnya. Pada kegiatan ekstrakulikuler para santri disuguhkan berbagai kegiatan belajar baik yang sudah ditentukan pesantren (kegiatan wajib) maupun kegiatan pilihan mulai dari pembelajaran dan penguasaan bahasa asing, belajar pidato, program pengayaan melalui halaqah-halaqah, program keterampilan melalui kursus-kursus, pelatihan organisasi dan administrasi, kegiatan olahraga dan seni. Para santri biasanya membentuk kelompokkelompok kegiatan sesuai pilihannya di bawah koordinasi ustadz yunior atau santri senior yang tergabung dalam organisasi santri.

Penjelasan di atas menunjukkan bahwa keadaan metode pembelajaran di pesantren mulai berubah, kelompok-kelompok diskusi telah berkembang di mana-mana, belajar dengan CBSA dan cara-cara memecahkan masalah semakin membudaya. Kesadaran bahwa metodologi belajar mengajar pada akhirnya harus membawa anak didik untuk belajar lebih lanjut dan berkemampuan memilih serta lebih mengutamakan proses belajar dalam perspektif " menjadi' di atas perspektif "memiliki". Metodologi semacam ini tak terelakan lagi, kecuali mengenai hal-hal yang memang sudah di nash untuk dihafal (Mastuhu, 1997: 35)

Proses pendidikan terjadi dalam lingkungan interaksi edukatif antara guru dengan murid melalui metodologi. Pembaharuan metodologi berakar pada kenyataan bahwa tidak ada metode mengajar yang lebih baik dan efektif karena setiap metode memiliki

\footnotetext{
${ }^{19}$ Mahmud Yunus, Sejarah Pendidikan di Indonesia, (Jakarta : Hidakarya, 1990), hlm.50. Metode ini hanya baik untuk santri yang cerdas sementara bagi santri yang lain hanya sebagai partisipan yang tidak aktif.
} 


\section{Pembaharuan Sistem Pendidikan Islam di Pesantren Husnul Amin}

kelebihan dan kekurangan. Oleh karena itu, metode yang digunakan dalam pengajaran sebaiknya tidak terbatas pada satu metode atau beberapa metode saja tapi harus disesuaikan dengan kondisi anak didik dan pelajaran yang disampaikan sehingga metode yang digunakan dapat mewujudkan tujuan pendidikan dengan baik.

\section{d. Aspek Pendidik di pesantren}

Pendidik adalah orang yang melakukan kegiatan dalam bidang pendidikan. Dalam bahasa Inggris disebut dengan teacher (guru), instructor atau trainer (pemandu), lecture (dosen). Dan educator (pendidik). Dan dalam bahasa arab juga disebut dengan ustazd, mudarris, mu'alim, dan mu'addib. ${ }^{20}$

Pendidik merupakan di antara komponen pendidikan yang harus diperhatikan. Karena pendidik bertanggung jawab dalam pembentukan pribadi peserta didiknya. Seorang pendidik tidak hanya berfungsi sebagai pengajar di kelas saja, melainkan harus mampu menciptakan suasana pergaulan yang edukatif di luar kelas. ${ }^{21}$ Pendidik juga memberi kesempatan kepada perserta didik untuk melakukan berbagai kegiatan guna memecahkan masalah (how to think bukan what to think) (Nasution, 2004: 24-25).

Menurut Undang-undang RI Nomor 20 Tahun 2003 tentang Sistem Pendidikan Nasional dinyatakan bahwa pendidik merupakan tenaga professional yang bertugas merencanakan dan melaksanakan proses pembelajaran, melakukan bimbingan dan pelatihan, serta melakukan penelitian dan pengabdian kepada masyarakat. ${ }^{22}$

Dengan tugas dan tanggung jawab yang kuat itulah, maka seorang pendidik dituntut memenuhi beberapa syarat. Menurut Direktorat Pendidikan Agama, syaratsyarat sebagai pendidik atau pengajar adalah ; pertama, memiliki kepribadian Mukmin, Muslim dan Muhsin. Kedua, taat untuk menjalankan Agama, yaitu menjalankan syari'at Islam, dan dapat memberikan contoh teladan yang baik bagi peserta didiknya. Ketiga,

\footnotetext{
${ }^{20}$ Dalam Al-Qur' an dapat dipahami ada beberapa istilah pendidik seperti; ulama (orang yang berilmu pengetahuan), al-rasikhuna fi al-ilm 9orang yang memiliki kemampuan melakukan penalaran secara mendalam), ahl dzikr (orang yang senantiasa memberkan peringatan agar orang lain tidak terjerumus ke jalan hidup yang sesat), al-murabbi (orang yang mampu membina, emngarahkan dan meningkatkan segenap potensi yang dimiliki manusia agar trbentuk pribadi yang utama), al-muzakki (orang yang mampu membentuk manusia yang senantiasa terhindar dari perbuatan yang keji dan mungkar dan menjadi mansuia yang berahlak mulia), ulul albab (orang yang senantiasa mempergunakan akalnya untuk berpikir, dan hatinya untuk berzikir serta mengupayakan anak didiknya agar menjadi manusia yang memiliki keseimbangan antara kecerdasan intelektual dan kecerdasan emosionalnya), al-muwa' idz (orang yang senantiasa mengigatkan, menasehatkan dan menjaga anak didiknya dari pengaruh yang berbahaya), dan al-mudarris (orang yang sensntiasa melakukan kegiatan ilmiah dan berupaya mengajarkan dan membimbing para siswanya agar memiliki tradisi ilmiah yang kuat). Lihat: Abuddin Nata, Pendidikan dalam Perpektif al-Qur' an, Jakarta: UIN Jakarta Press, 2005), hlm.127-153; Bandingkan: Abuddin nata dan fauzan, (ed)., Pendidikan dalam Perspektif hadits (Jakarta:UIN Jakarta Press,2005), hlm. 206-207.

${ }^{21}$ Disamping itu, seorang pendidik juga memiliki pribadi yang berjiwa luhur dan bekerja penuh pengabdian. Mereka terus-menerus memberikan jasa-jasa tanpa mengharapkan imbalan dari peserta didik. Departemen Pendidikan dan Kebudayaan, Guru Pahlawan Nasional Tanpa Tanda jasa (Jakarta; Aries Lima, 1984), hlm. 14.

${ }^{22}$ Senada dengan itu, dalam Undang-undang RI Nomor 14 tahun 2005 tentang Guru dan Dosen juga dijelaskan bahwa pendidik/guru adalah tenaga professional yang tugas utamanya mendidik, mengajar, membimbing, mengarahkan, melatih, menilai, dan mengevaluasi peserta didik pada pendidikan anak usia dini, jalur pendidikan formal, pendidikan dasar, dan pendidikan menengah. Lihat:Undang-Undang RI Nomor 20 tahun 2003 tentang Sistem Pndidikan Nasional; Bandingkan: Lihat: Undang-undang RI Nomor 14 Tahun 2005 tentangg guru dan Dosen Pasal I ayat 1 .
} 
Volume 1 Nomor 1 Edisi Juni 2016

P-ISSN : 2541-3686

memiliki jiwa pendidik dan kasih sayang kepada peserta didiknya serta berjiwa ikhlas. Keempat, mengetahui dasar-dasar pengetahuan tentang keguruan, terutama didaktik metodik. Kelima, menguasai ilmu pengetahuan Agama. Keenam, sehat rohani dan jasmaninya (Zuhairini dkk., 1983: 36).

Sedangkan menurut Undang-undang RI Nomor 20 tahun 2003, persyaratan (kualifikasi) seorang pendidik tersebut adalah; pertama, pendidik harus memiliki kualifikasi minimum dan sertifikasi dengan jenjang kewenangan mengajar, sehat jasmani dan rohani, serta memiliki kemampuan untuk mewujudkan tujuan pendidikan nasional. Kedua, pendidik untuk pendidikan formal pada jenjang pendidikan usia dini, pendidikan dasar, menengah, dan pendidikan tinggi dihasilkan oleh perguruan tinggi yang terakreditasi (Undang-undang RI Nomor 20 Tahun 2003 tentang Sistem Pendidikan Nasional, Pasal 42).

Secara lebih mendetail. UU Guru dan Dosen juga menjelaskan bahwa harus ada beeberapa prinsip yang melekat pada diri seorang pendidik, yaitu; pertama, memiliki bakat, minat, panggilan jiwa, dan idealisme. Kedua, memiliki komitmen untuk meningkatkan mutu pendidikan, keimanan, ketakwaan, dan ahlak mulia. Ketiga, memiliki kualifikasi akademik dan latar belakang pendidikan sesuai dengan bidang tugas. Kelima, memiliki tanggung jawab atas pelaksanaan tugas keprofesionalan, keenam, memperoleh penghasilan yang ditentukan sesuai dengan prestasi kerja. Ketujuh, memiliki kesempatan untuk mengembangkan keprofesoanalan secara berkelanjutan dengan belajar sepanjang hayat. Kedelapan, memiliki jaminan perlindungan hukum dalam melaksanakan tugas keprofesionalan, dan kesembilan, memiliki organisasi profesi yang mempunyai kewenangan mengatur hal-hal yang berkaitan dengan tugas keprofesionalan guru (Undang-Undang RI No. 14 Tahun 2005 Tentang Guru dan Dosen Pasal 7 ayat 1).

Ketentuan lebih lanjut tentang pendidik juga diatur dalam Peraturan Pemerintah Nomor 19 Tahun 2005 tentang Standar Nasional Pendidikan terutama dalam Bab VI, Pasal 28;

1. Pendidik harus memiliki kualifikasi akademik dan kompetensi sebagai agen pembelajaran, sehat jasmani dan rohani, serta memiliki kemampuan untuk mewujudkan tujuan nasional.

2. Kualifikasi akademik sebagaimana yang dimaksud ayat (1) adalah tingkat pendidikan minimal yang harus dimikiki oleh seorang pendidik yang harus dibuktikan dengan ijazah dan/atau sertifikasi keahlian yang relevan sesuai peraturan perundang-undangan yang berlaku.

3. Kompetensi sebagai agen pembelajaran pada jenjang pendidik dasar dan menengah serta pendidik usia dini.

4. Seorang yang tidak memiliki ijazah/sertifikasi keahlian sebagaimana dimaksud pada ayat (2) tetapi memiliki keahlian khusus yang diakui dan diperlukan dapat diangkat menjadi pendidik setelah melalui uji kelayakan dan kesetaraan (Peraturan Pemerintah RI nomor 19 Tahun 2005 tentang Standar Nasional Pendidikan). 


\section{Pembaharuan Sistem Pendidikan Islam di Pesantren Husnul Amin}

Berdasarkan pijakan ini, dapat dipahami bahwa karakteristik seorang guru yang bermutu harus memiliki kualifikasi akademik, ${ }^{23}$ kompetensi ${ }^{24}$ dan sertifikasi. ${ }^{25}$

Bicara masalah mutu berarti bicara masalah kompetensi. Menurut Muji Hariani dan Noeng Muhajir, sebagaimana yang dikutip Syafrudin Nurdin, setidaknya terdapat tiga model kompetensi (performance pendidik) dalam melaksanakan proses belajar mengajarnya yang dikenal dengan Stanford Teacher of Appraisal Competence (STAC);

1. Model Rob Norris. Di mana kompetensi guru itu mencakup; kualitas personal dan professional, persiapan pengajaran, perumusan tujuan pengajaran, penampilan guru dalam mengajar, penampilan siswa dalam belajar, dan evaluasi.

2. Model Oregon. Yaitu, kompetensi yang harus dimiliki oleh guru meliputi; perencanaan dan persiapan mengajar, kemampuan guru dalam mengajar dan kemampuan siswa dalam belajar, kemampuan mengumpulkan dan menggunakan informasi hasil belajar, kemampuan hubungan interpersonal yang meliputi hubungan dengan siswa, supervisor, dan guru sejawat, dan kemampuan hubungan dengan tnggung jawab professional.

3. Model Stanford. Meliputi komponen tujuan, komponen guru mengajar dan komponen evaluasi (Nurdin, 91-92).

Pembaharuan pendidik berorientasi pada peningkatan mutu pendidik yang dapat ditandai dengan adanya usaha dalam pencapaian kompetensi yang melekat pada diri seorang pendidik.

\section{e. Aspek Peserta Didik}

Dalam pendidikan Islam, istilah lain untuk peserta didik antara lain adalah al-shabiy (anak-anak), murid (orang yang menginginkan atau membutuhkan), al muta'alim (pelajar), thalib al-ilmi (penuntut ilmu pengetahuan), tilmiz (murid-murid), dan thifl (orang yang berhajat) (Arief, 2002: 74). Yang dimaksud dengan peserta didik adalah orang atau sekelompok orang yang tengah memerlukan pengetahuan atau ilmu, bimbingan, dan pengarahan. Karena peserta didik dilahirkan dalam keadaan suci, bersih dari segala dosa, maka dia akan menjadi baik atau buruk tergantung kepada pendidik dan lingkungannya (Nata, 2005: 143).

Menurut Abuddin Nata, seorang yang tengah mencari ilmu memerlukan kesiapan fisik yang prima, akal yang sehat, pikiran yang jernih, dan jiwa yang tenang, maka perlu adanya upaya memlihara dan merawat sungguh-sungguh terhadap potensi dan alat indra, fisik, dan mental yang diperlukan untuk mencari ilmu. Peserta didik berfungsi sebagai objek yang sekaligus sebagai subjek pendidikan. Sebagai objek karena peserta didik tersebut menerima perlakuan-perlakuan tertentu, tetapi dalam pandangan

\footnotetext{
${ }^{23}$ Kualifikasi akademik untuk guru diperoleh melalui pendidikan tinggi program sarjana atau program diploma IV, Undang-undang RI Nomor 14 tahun 2005 tentang guru dan Dosen Pasal 9.

${ }^{24}$ Sedangkan kompetensi yang harus dipenuhi guru meliputi kompetensi pedagogic, kompetensi kepribdian, kompetensi sosial, dan kompetensi professional. Undang-undang RI Nomor 14 Tahun 2005 tentang Guru dan Dosen Pasal 10.

${ }^{25}$ Sertifikasi pendidik diperoleh guru setelah mengkuti program sertifikasi yang diselenggarakan oleh Perguruan Tinggi yang dimiliki program pengadaan tenaga kependidikan yang terakreditasi dan ditetapkan oleh pemerintah. Undang-undang RI Nomor 14 Tahun 2005 tentang Guru dan Dosen Pasal 11.
} 
RAUDHAH Proud To Be Professionals Jurnal Tarbiyah)damiyah

Volume 1 Nomor 1 Edisi Juni 2016

P-ISSN : 2541-3686

pendidikan modern perserta didik lebih dekat dikatakan sebagai subjek atau pelaku pendidikan (Nata, 2005: 143).

Usaha pembaharuan pendidikan ditujukan untuk kepentingan siswa atau peserta didik, yang sering disebut "Student Centered Approach" (Hasbullah, 2005: 202). Pembaharuan tersebut berorientasi untuk menghasilkan sosok peserta didik yang ideal. Seperti; berkualitas, professional, mumpuni dibidangnnya, berkemauan keras atau pantang menyerah, memiliki motivasi yang tinggi, sabar, tabah, tidak mudah putus asa dan lain sebagainya.

Upaya ini dapat dilakukan dengan cara membenahi proses atau pendidikan. Artinya, pembaharuan terhadap peserta didik berawal dari pembaharuan terhadap input (calon siswa yang akan masuk) lewat penyeleksian yang ketat, kemudian dilakukan penggondokan dan pemantapan keilmuan dalam kegiatan belajar mengajar (proses) di sekolah dan di asrama untuk menghasilkan out-put yang diharapkan.

\section{DAFTAR PUSTAKA}

Abdul Fatah, Rohandi, dkk. 2005. Rekontruksi Pesantren Masa Depan,Jakarta : Listafariska Putra.

al-Jamaly, M. Fadhil. 1986. Filsafat Pendidikan dalam al-Qur'an, Surabaya: PT. Bina Ilmu.

Arief, Armai. 2002. Pengantar Ilmu dan Metodologi Pendidikan, Jakarta: Ciputat Press.

Arifin M., 1987. Filsafat Pendidikan Islam, Jakarta: Bumi Aksara.

Bernadib, Imam. 1994. filasafat Pendidikan: Sistem \& Metode,Yogyakarta: ANDI

Guntur Tarigan, Hendry. 1993. Dasar-dasar Kurikulum Bahasa, Bandung:Angkasa.

Hadi, M. Syamsul dkk. 2002. Pengembangan Metodologi Pembelajaran Pesantren Salafiyah, Jakarta: Diva Pustaka

Hasbullah. 2005. Dasar-dasar Ilmu Pendidikan, Jakarta: PT. RajaGrafindo Persada,

Hirzin, M. Habib, 1995. Ilmu dan Agama dalam Pesantren, Jakarta, LP3ES,.

Langgulung, Hasan, 1995. Manusia dan Pendidikan ,Jakarta:Husna Zikra.

Mastuhu. 1999. Memberdayakan Sistem Pendidikan Islam. Jakarta: Logos

-----.,1994. Dinamika Sistem Pendidikan Pesantren Suatu Kajian Tentang Unsur dan

Nilai Sistem Pendidikan Pesantren, Jakarta: INIS.

----,. 1999. Memberdayakan Sistem Pendidikan Islam, Jakarta: Logos Wacana Ilmu.

-----,. 1980. Pengantar filsafat Pendidikan, Bandung : al-Ma'arif.

----,.1988. Prinsip - prinsip Pendidikan Islam, Jakarta : P3M

Madjid, Nurcholis.1997. Bilik-bilik Pesantren: Sebuah Potret Perjalanan. Jakarta: Paramadina.

Marwan, Saridjo. 1979. Sejarah Pondok Pesantren di Indonesia, Jakarta: Dharma Bakti. 


\section{Pembaharuan Sistem Pendidikan Islam di Pesantren Husnul Amin}

Nata Abuddin dan Fauzan. 2005. (ed) Pendidikan dalam Perspektif Hadits,Jakarta: UIN Jakarta Press.

Noor Syam, Mohammad, 1986. Filsafat Kependidikan dan Dasar Filsafat Kependidikan Pancasila, cet.III, Surabaya:Usaha Nasional.

Nasution, S. 2003. Asas-Asas Kurkulum, Jakarta: Bumi Aksara.

Peraturan Pemerintah RI nomor 19 Tahun 2005 tentang Standar Nasional Pendidikan.

Raharjo, M. Dawam. 1985. Pergulatan Dunia Pesantren Membangun dari Bawah, Jakarta : P3M

Ramayulis. 2010. Ilmu Pendidikan Islam, Jakarta: Kalam Mulia.

Sukmadinata, Nana Syaodih.1999. Pengembangan Kurikulum: Teori dan Praktek, Bandung: Remaja Rosdakarya

Soetopo, Hendyat dan Soemanto, wasty. 1993. Pembinaan dan Pengembangan Kurikulum Sebagai Substansi Problem Administrasi Pendidikan, Jakarta: Bumi Aksara.

Suryanto. 2000. Refleksi dan Reformasi Pnedidikan di Indonesia Memasuki Milenium III, Jakarta:Adicita.

Syukri Zarkasyi, Abdullah. 2005. Manajemen Pesantren Pondok Pesantren Modern Gontor, Ponorogo: Trimurti Press

Undang-undang RI Nomor 20 Tahun 2003 tentang Sistem Pendidikan Nasional.

Undang-undang RI Nomor 14 Tahun 2005 tentangg guru dan Dosen.

Wijaya, Cece et.al. 1992. Upaya Pembaharuan dalam Pendidikan dan Pengajaran. Bandung: PT.Remaja Rosdakarya.

Zarkasyi, Imam. 1973. Beberapa Pokok Pikiran Tentang Pondok Pesantren.

Yunus, Mahmud. 1990. Sejarah Pendidikan di Indonesia, Jakarta : Hidakarya.

Zuhairini dkk. 1983. Metodik Khsusu Pendidikan Agama, Surabaya: Usaha Nasional. 